\title{
Pelatihan Pembuatan Hand Sanitizer yang Lembut di Kulit dalam Pencegahan Covid-19 di Kalangan Siswa SMA
}

\author{
Training on Making Soft Hand Sanitizer for Skin in The Prevention of Covid-19 among High \\ School Students
}

Rizka Novia Atmadani
Department of Pharmacy, Universitas
Muhammadiyah Malang, Malang,
East Java, Indonesia
email: rizkanovia@umm.ac.id
Kata Kunci
Alkohol
Covid-19
Hand sanitizer
Pelatihan
Siswa
SMA
Keywords:
Alcohol
Covid-19
Hand sanitizer
Training
Student
Senior High School
Received: March 2021
Accepted: September 2021
Published: October 2021

\begin{abstract}
Abstrak
Masalah Covid 19 yang menjadi pandemi saat ini merupakan masalah yang harus dicegah penularannya dengan melaksanakan protokol kesehatan yang ketat utamanya dengan penggunaan hand sanitizer yang konsenstrasi dan komposisinya benar sehingga ampuh membunuh mikroorganisma pada tangan. Pembuatan hand sanitizer menggunakan Alkohol dengan konsentrasi antara 65-95\% merupakan salah satu bahan yang efektif memutus rantai penularan Covid-19. Kegiatan pelatihan ini dilakukan kepada siswa anggota PMR SMAN 7 Kediri melalui tahapan persiapan, penyuluhan dengan pretes dan postes, dan praktek pembuatan hand sanitizer. Produk hand sanitizer yang dhasilkant diberikan kepada seluruh siswa dan pihak sekolah. Hasil skor pretes dan postes disimpulkan bahwa ada kenaikan pengetahuan siswa terhadap materi yang diberikan sehingga harapannya para siswa mampu membuat sendiri di rumah dan dapat berperan untuk memutus rantai penyebaran Covid-19.
\end{abstract}

\begin{abstract}
The problem of Covid 19, which has become a pandemic, is a problem that must be prevented by implementing strict health protocols, especially with the use of hand sanitizers that have correct concentration and correct composition that effectively kill microorganisms on the hands. Making hand sanitizers using alcohol with $65-95 \%$ concentration is one of the effective ingredients to break the chain of transmission of Covid-19. This training activity was carried out for students of PMR members of SMAN 7 Kediri through the stages of preparation, counseling with pretest and posttest, and the practice of making hand sanitizers. The hand sanitizer products that are produced are given to all students and the school. The pretest and posttest scores concluded that there was an increase in students' knowledge of the education provided. Hopefully, the students could make their hand sanitizer at home and could play a role in breaking the chain of the spread of Covid-19.
\end{abstract}

(C) 2021 Rizka Novia Atmadani. Published by Institute for Research and Community Services Universitas Muhammadiyah Palangkaraya. This is Open Access article under the CC-BY-SA License (http://creativecommons.org/licenses/by-sa/4.0/). DOI: https://doi.org/10.33084/pengabdianmu.v6i6.2171

\section{PENDAHULUAN}

Saat ini dunia sedang dilanda krisis kesehatan akibat penularan covid-19 (corona virus disease) atau lebih dikenal dengan virus corona. Virus ini merupakan virus corona jenis baru dari SARS-CoV-2 yang awalnya ditemukan di Wuhan ibukota provinsi Hubei China pada akhir tahun 2019 dan telah diumumkan oleh World Health Organizations (WHO) sebagai pandemi pada 11
Maret 2020 (Susilo et al., 2020; Yuliana, 2020). Pandemi Coronavirus di Indonesia diawali dengan temuan penderita Covid-19 pada 2 Maret 2020. Hingga 15 April 2020, telah terkonfirmasi 4.839 kasus positif Covid-19 dengan 459 kasus meninggal (9,49\%). Dan sekarang, 287.008 kasus terkonfirmasi positif untuk Indonesia dengan Propinsi Jawa Timur berada pada posisi ke 2 yaitu dengan 43.744 kasus positif (Satuan Tugas 
Penanganan Covid-19, 2020). Masalah Covid 19 yang menjadi pandemi saat ini merupakan masalah yang harus dihadapi bersama dengan salah satunya adalah mencegah penularan virus ini dengan melaksanakan protokol kesehatan yang ketat (Pujaningsih \& Sucitawathi, 2020). Salah satu protokol kesehatan yang sehari-hari harus kita biasakan adalah penggunaan hand sanitizer yang konsenstrasi dan komposisi senyawanya benar sehingga ampuh membunuh mikroorganisma pada tangan (Jing et al., 2020).

Penggunaan alkohol sebagai basis pada hand sanitizer yang efektif adalah pada prosentase 62-95\% dimana pada rentang konsentrasi ini, dapat mendenaturasi protein pada mikroba dan menginaktivasi virus (Sianipar et al., 2021; Hilburn et al., 2003). Selain dengan bahan aktif dari Alkohol dan turunannya, pembuatan hand sanitizer juga dapat dibuat dari bahan alam seperti Daun Sirih, seperti yang dilakukan pada sebuah pelatihan di Pasuruan (El-Sulukiyyah et al., 2020). Namun pada kali ini dipilih bahan aktif berupa alkohol untuk pembuatan hand sanitizer.

Di Kota Kediri menurut data statistik pada website https://corona.kedirikota.go.id/ menunjukkan terus naiknya pasien positif dengan angka 192 pasien per tanggal 30 September 2020, 152 sembuh, dan 10 meninggal dunia (Dinas Komunikasi dan Informatika Kota Kediri, 2020). Saat ini masih banyak masyarakat Kota Kediri khususnya para remaja yang masih lalai dalam mematuhi protokol kesehatan seperti menggunakan masker dan mencuci tangan atau menggunakan hand sanitizer. Hal tersebut harus dicegah sedari dini dan perlu dilakukan edukasi serta pelatihan khusus untuk meningkatkan kesadaran patuh protokol Covid-19 khususnya pengenalan tentang betapa pentingnya penggunaan hand sanitizer berbasis alkohol dengan konsentrasi yang tepat.

\section{METODOLOGI}

Metode kegiatan pengabdian masyarakat dengan pelatihan pembuatan hand sanitizer dibagi menjadi beberapa tahapan, yakni persiapan, penyuluhan, dan praktik pembuatan hand sanitizer sebagai berikut:

1. Tahap persiapan

Pada tahapan ini, pelaksana mempersiapkan semua kebutuhan yang diperlukan seperti halnya materi penyuluhan, alat praktik, dan bahan yang akan digunakan untuk membuat hand sanitizer. Sebelumnya, pengabdi telah menghubungi para siswa SMA yang tergabung dalam Organisasi Palang Merah Remaja di SMA Negeri 7 Kediri untuk mengikuti kegiatan pengabdian.

2. Tahap penyuluhan

Sebelum penyuluhan dilaksanakan, dilakukan tes awal (pretest) kepada peserta menggunakan lima soal tentang hand sanitizer, tujuannya untuk melihat pengetahuan dasar peserta (Atmadani et al., 2021; Yunita \& Atmadani, 2021). Selanjutnya setelah pretest, akan dilakukan penyuluhan. Pada tahapan penyuluhan ini, para siswa diberikan pengetahuan terkait bahan aktif dalam hand sanitizer dan prosentase yang efektif dalam membunuh mikroorganisme di tangan serta formula yang tepat yang mengacu pada standar WHO (Gold et al., 2021).

3. Tahap praktek pembuatan hand sanitizer

Pelaksana mempraktekkan langsung pembuatan hand sanitizer kepada para siswa. Selanjutnya para siswa praktek sendiri untuk pembuatan hand sanitizer mereka sesuai dengan yang diarahkan oleh pelaksana pengabdian. Pelaksana juga memberikan jawaban apabila ada siswa yang bertanya terkait materi. Selanjutnya pelaksana memberikan evaluasi akhir (posttest) kepada peserta guna mengukur efektifitas penyuluhan dan bertambahnya pengetahuan peserta sebagai luaran kegiatan ini. 


\section{HASIL DAN PEMBAHASAN}

Kegiatan pelatihan ini dilakukan pada tanggal 23 Januari 2021 di Laboratorium Kimia SMA Negeri 7 Kediri yang dihadiri oleh 22 siswa PMR yang mana adalah sasaran dari kegiatan ini yang perlu dilakukan dalam upaya pencegahan Covid-19. Kegiatan ini diawali oleh pretest yang dikerjakan oleh para siswa untuk mengukur wawasan awal mereka terhadap hand sanitizer (Atmadani \& Hidayati, 2020). Kemudian dilanjutkan dengan penyuluhan materi edukasi terkait hand sanitizer seperti kandungan hand sanitizer yang efektif untuk membunuh mikroorganisme, prosentase yang paling efektif, betapa pentingnya penggunaan hand sanitizer berbasis alkohol dalam memutus rantai penyebaran Covid-19, dan bagaimana formula yang tepat yang dianjurkan oleh WHO untuk membuat hand sanitizer yang lembut di tangan dan pembuatannya mudah dengan bahan-bahan serta alat-alat yang mudah dijangkau oleh masyarakat umum.

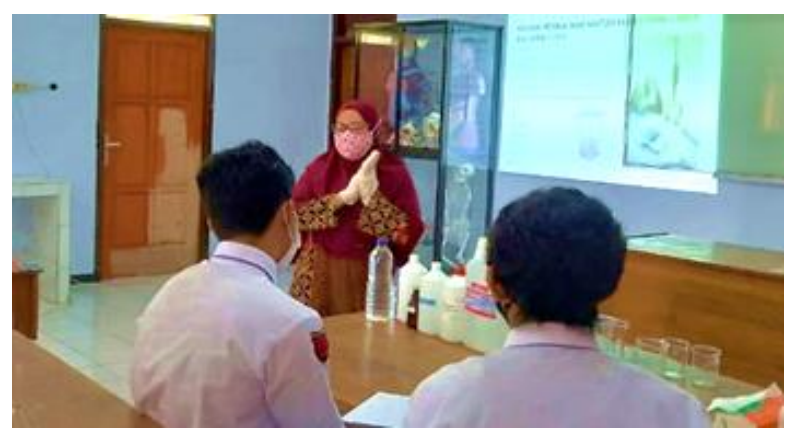

Gambar 1. Pemberian materi edukasi tentang hand sanitizer

Formula yang dianjurkan oleh WHO sebagaimana tertera dalam pedoman yang ditulis oleh Gold et al. (2021). Untuk membuat konsentrasi akhir dengan bahan-bahan dari etanol $80 \% \mathrm{v} / \mathrm{v}$, gliserin $1,45 \% \mathrm{v} / \mathrm{v}$, hidrogen peroksida $\left(\mathrm{H}_{2} \mathrm{O}_{2}\right) \quad 0,125 \% \mathrm{v} / \mathrm{v}$, langkahlangkahnya adalah sebagai berikut:

1. Siapkan wadah untuk kapasitas $1000 \mathrm{ml}$.

2. Masukkan etanol $96 \%$ sebanyak $833,3 \mathrm{ml}$ ke wadah.

3. Tambahkan hidrogen peroksida $3 \%$ sebanyak 41,7 $\mathrm{ml}$.
4. Tambahkan gliserin $98 \%$ sebanyak $14,5 \mathrm{ml}$.

5. Langkah terakhir yaitu tambahkan akuades sampai pada batas $1000 \mathrm{ml}$ lalu digojok dengan perlahan.

6. Masukkan pada botol semprot yang sudah disediakan.

Setelah penyuluhan seputar hand sanitizer dan formula pembuatan sesuai $\mathrm{WHO}$, pelaksana mempraktekkan di depan siswa cara pembuatan hand sanitizer tersebut, yang kemudian diikuti oleh seluruh siswa hingga. Langkah terakhir yaitu dimasukkan ke dalam botol semprot yang sebelumnya sudah disiapkan oleh pelaksana seperti ditunjukkan pada Gambar 2. Botol hand sanitizer seperti pada Gambar 3 yang sudah jadi tersebut kemudian diberikan kepada seluruh siswa yang mengikuti pelatihan ini. Harapan pelaksana, setelah adanya pelatihan ini, para siswa dapat membuat hand sanitizer sendiri di rumah dengan formula ringan dan dengan alat serta bahan yang mudah dijangkau.

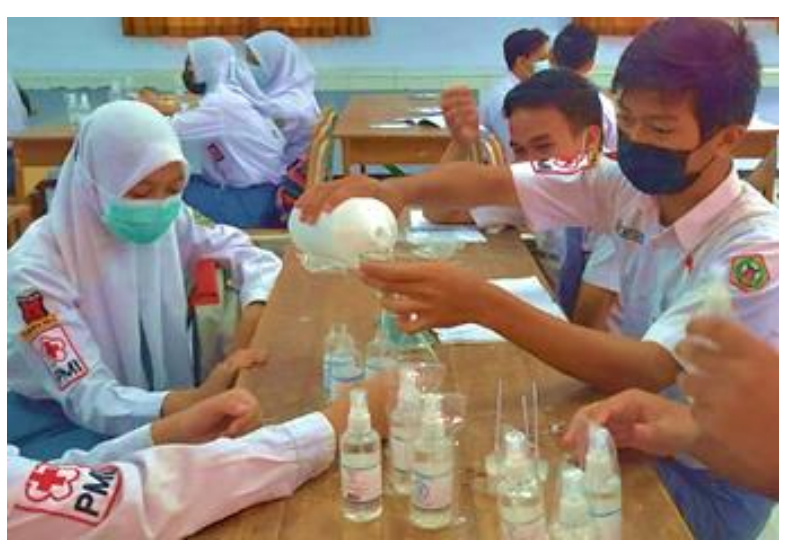

Gambar 2. Kegiatan praktek pembuatan hand sanitizer

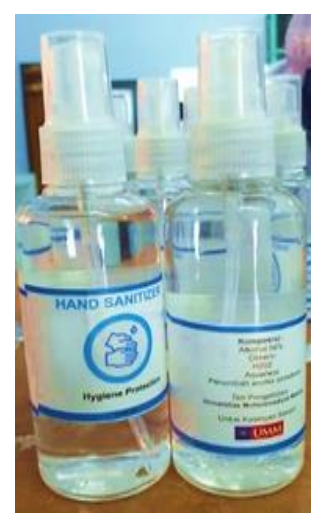

Gambar 3. Produk hand sanitizer yang dihasilkan 
Berdasarkan hasil pretest dan posttest siswa yang dilakukan, terlihat adanya peningkatan pengetahuan terhadap materi yang diberikan dan dilakukan pelatihan oleh pelaksana. Hasil pretest dan posttest dapat dilihat pada grafik pada Gambar 4 .

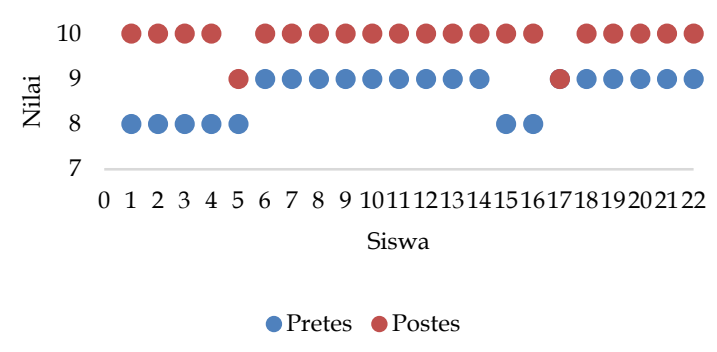

Gambar 4. Hasil skor pretest dan posttest

\section{KESIMPULAN}

Berdasarkan kegiatan pelatihan yang telah dilaksanakan pada tanggal 23 Januari 2021 ini disimpulkan bahwa kegiatan pelatihan berjalan lancar dengan 22 partisipan dari siswa anggota PMRSMAN 7 Kediri. Kegiatan mulai dari tahap persiapan sampai dengan tahap praktek pembuatan hand sanitizer menggunakan formula WHO yang juga dapat membuat lembut pada permukaan tangan. Dari hasil pretest dan posttest yang dilakukan para siswa didapatkan adanya kenaikan skor yang artinya ada peningkatan pengetahuan para siswa terhadap materi edukasi yang diberikan. Harapan pelaksana terhadap kegiatan pelatihan ini adalah para siswa mampu mempraktekkan dan membuat sendiri hand sanitizer di rumahnya sehingga dapat berperan aktif memutus rantai penyebaran virus Covid-19. Saran untuk kegiatan pengabdian selanjutnya adalah dapat mengajarkan para siswa untuk membuat hand sanitizer dengan formula berbasis gel.

\section{UCAPAN TERIMA KASIH}

Ucapan terima kasih pelaksana sampaikan kepada Kepala Sekolah SMAN 7 Kediri, Para Guru Pembina PMR yang membantu jalannya acara pelatihan ini, dan adik-adik Siswa PMR SMAN 7 Kediri yang bersedia menjadi peserta pada kegiatan pengabdian masyarakat kali ini.

\section{REFERENSI}

Atmadani, R.N., Hidayati, I.R. 2020. Pelatihan Apoteker Cilik dan DaGuSiBu bagi Siswa SDN Losari di Singosari, Kabupaten Malang. Jurnal Pengabdian UNDIKMA. 1(2):77-81. https://doi.org/10.33394/jpu.v1i2.2966

Atmadani, R.N., Yunita, S.L., Hidayati, I.R., Aldila, A.O., Rizqi, F.D. 2021. Penyuluhan Perilaku Hidup Bersih dan Sehat (PHBS) sebagai Upaya Preventif dalam Memutus Rantai Penyebaran Covid-19 pada kalangan Mahasiswa Baru Farmasi. To Maega: Jurnal Pengabdian Masyarakat. $\quad$ 4(2):153-159. http://dx.doi.org/10.35914/tomaega.v4i2.62 0

Dinas Komunikasi dan Informatika Kota Kediri. 2020. Kota Kediri Tanggap Covid 19. https://corona.kedirikota.go.id/

El-Sulukiyyah, A.A., Ulum, M.M., Pusparini, D.A. 2020. Pelatihan Pembuatan Hand Sanitizer Daun Sirih Sebagai Upaya Pencegahan Penyebaran Covid-19. di Desa Jarangan Pasuruan. JAMAIKA: Jurnal Abdi Masyarakat.1(3):133-139.

Gold, N.A.,Mirza, T.M., Avva, U. 2021. Alcohol Sanitizer. In StatPearls. Florida: Treasure Island.

Hilburn, J., Hammond, B.S., Fendler, E.J., Groziak, P.A. 2003. Use of alcohol hand sanitizer as an infection control strategy in an acute care facility. American Journal of Infection Control. 31(2):109-116.

https://doi.org/https://doi.org/10.1067/mi c. 2003.15

Jing, J.L.J., Yi, T.P., Bose, R.J.C., McCarthy, J.R., Tharmalingam, N., Madheswaran, T. 2020. Hand Sanitizers: A Review on Formulation Aspects, Adverse Effects, and Regulations. International Journal of Environmental Research and Public Health. 17(9):3326. https://doi.org/10.3390/ijerph17093326

Pujaningsih, N.N., Sucitawathi, I.G.A.A.G.D. 2020. Penerapan Kebijakan Pembatasan Kegiatan Masyarakat (PKM) Dalam Penanggulangan 
Wabah Covid-19 Di Kota Denpasar. Moderat: Jurnal Ilmiah Ilmu Pemerintahan. 6(3):458-470. http://dx.doi.org/10.25157/moderat.v6i3.35 37

Satuan Tugas Penanganan Covid-19. 2020. Data Sebaran Virus COVID-19 di Indonesia. https://covid19.go.id/peta-sebaran

Sianipar, H.F., Siahaan, T.M., Siahaan, M.M., Saragih, M. 2021. Diseminasi Hand Sanitizer Mampu Mengurangi Pertumbuhan Mikroba Di Siantar Estate. Mitra Mahajana: Jurnal Pengabdian Masyarakat. 2(1):55-63. https://doi.org/10.37478/mahajana.v2i1.803

Susilo, A., Rumende, C.M., Pitoyo, C.W., Santoso, W.D., Yulianti, M., Herikurniawan, H., Sinto, R., Singh, G., Nainggolan, L., Nelwan, E.J., Chen, L.K., Widhani, A., Wijaya, E., Wicaksana, B., Maksum, M., Annisa, F., Jasirwan, C.O.M., Yunihastuti, E. 2020. Coronavirus Disease 2019: Tinjauan Literatur Terkini. Jurnal Penyakit Dalam Indonesia. 7(1):45-67. http://dx.doi.org/10.7454/jpdi.v7i1.415

Yuliana, Y. 2020. Corona virus diseases (Covid-19): Sebuah tinjauan literatur. Wellness and Healthy Magazine.

2(1):187-192. https://doi.org/10.30604/well.95212020

Yunita, S.L., Atmadani, R.N. 2021. IBM DaGuSiBu Obat Dan Pemeriksaan Kesehatan Bagi Pekerja Migran Indonesia (PMI) Di Taipei, Taiwan. Selaparang: Jurnal Pengabdian Masyarakat Berkemajuan. 4(2):205-209. https://doi.org/10.31764/jpmb.v4i2.4355 